\title{
The factorial structure of self-reported androgen-promoted physiological traits
}

\author{
Lee Ellis ${ }^{1}$, Shyamal Das ${ }^{2}$ \\ ${ }^{1}$ University Malaya, Department of Anthropology, Kuala Lumpur, Malaysia; lee.ellis@hotmail.com; \\ ${ }^{2}$ Elizabeth City State University, Elizabeth City, USA; sdas@mail.ecsu.edu.
}

Received 27 June 2010; revised 29 July 2010; accepted 4 August 2010.

\begin{abstract}
Androgens make major contributions to average sex differences in anatomy, physiology, and behavior. Despite having established their crucial role in sexual differentiation, much remains to be learned about how androgens coordinate their influences. The present study was undertaken to shed light on androgenic effects on the body using self-reported survey data. We analyzed the ratings provided by over 11,000 college students on the magnitude of eleven traits that previous research has shown to be influenced by testosterone or other androgens. Predictably, the average values for all eleven traits were significantly greater in males than in females. Nevertheless, when data were analyzed separately according to sex of the respondents, some of the traits failed to positively correlate with one another, suggesting that not all androgen-influenced traits differentiate in a simple fashion. Factor analysis of these eleven traits by sex reinforced this view by identifying four factors. In men, the primary factor loaded most heavily on: masculine body build, masculine mannerisms, overall physical strength, upper body strength, and lower body strength. The primary factor for women was limited to: upper body strength, lower body strength, and overall physical strength. In both sexes, the primary factor was interpreted as reflecting the influence of perinatal and postpubertal testosterone exposure. The other three factors may reflect the effects of other androgens (e.g., androstenediol), or the influence of female hormones such as estradiol. Findings were discussed in terms of future use of self-reported physiological measures for assessing androgenic effects on the human body.
\end{abstract}

Keywords: Androgen-promoted physical traits;
Testosterone; Masculinization; Physical strength; Factorial structure; Sex differences

\section{INTRODUCTION}

A recent literature review provided evidence that the sexes differ in a mired of ways, ranging from easy-tomeasure traits (e.g., birth weights and adult body size) to many complex characteristics (e.g., susceptibility to numerous diseases, detailed biochemistry, neurology, perceptual sensitivities, motor coordination, and even many cognitive and behavioral patterns) [1]. This evidence raises questions about how sex differences are produced. Although the details are still far from fully understood, numerous studies have implicated bodily exposure to androgens as primarily responsible for sex differences in traits [2-5].

In broad terms, the sexual differentiation of animals occurs as follows: The default sex at least for mammals, is female, meaning that males are a genetic variant on the female sex [6-9]. Early in the gestation process of nearly all males, the would-be ovaries are made to begin differentiating into testes instead by genes located on the Y-chromosome [10]. As this occurs in humans during the first five months of gestation, the genitals of males gradually take on a masculine rather than a feminine appearance [11-12].

The gestational aspects of sexual differentiation are referred to as its organizational stage, a stage in humans extending from the first month of gestation into about the fourth month following birth [13]. The second phase of sexual differentiation is known as the activational (or postpubertal) stage. It is marked by the appearance of so-called secondary sex characteristics, but also includes enlargement of the penis and testes in males [14-17].

The traits that are masculinized by bodily exposure to androgens are numerous. They include the following:

- Growth of body hair [18-20]

- Darkening of the iris of the eye $[21,22]$

- Facial acne [23-25] 
- Darkening of hair color [26,27]

- Increase in height [28-32]

- Lowering of the voice [33-37]

- Increase in upper body strength $[15,38,39]$

- Increase in lower body strength $[40,42]$

- Increase in masculine body appearance [43-44]

- Increase in masculine mannerisms $[45,46]$

Despite the abundant evidence that androgens masculinize many aspects of human development, the details are still only vaguely understood. The purpose of the present study was to examine the eleven androgen-influenced traits listed above using self-ratings, with the following three questions in mind. First, are all of these traits in fact sexually dimorphic? Second, within each sex, how well do the eleven traits correlate with one another? Third, do the within-sex expressions of these traits cluster together, thereby suggesting that they may be resulting from a limited number of similar androgenic regimens?

\section{METHODS}

As part of a broad-ranging investigation, a standardized questionnaire was completed by a large sample of college students at twenty United States and two Canadian universities between 1988 and 1998 involving 3,786 males and 7,697 females [47]. Subjects ranged in age from 18 to 56, with a mean of 22 for both sexes. In terms of race and ethnicity, the subjects were $85 \%$ white, $4 \%$ black, 2\% Native American, 2\% Asian / Pacific Islander, $1 \%$ Hispanic, and $6 \%$ providing no answer.

Eight of the androgen-promoted physiological traits were measured by asking subjects to rate themselves regarding each trait using a 1 to 100 scale, with 100 representing maximum expression of each trait. These eight traits were: masculine mannerisms, masculine body appearance, physical strength, low deep voice, upper body strength, lower body strength, body-hair development, and facial acne. Height was measured simply in terms of feet and inches (converted to inches). Eye color and hair color were measured, first, by asking subjects to give a one- or two-word description of their eye color and natural hair color. These descriptions were then interpreted and transcribed into four categories. From highest to lowest values, eye color was coded as being Black, Brown, Hazel / Green, and Blue. For hair color, the four categories were Black, Dark Brown, Light Brown, and Blond. (A copy of the questionnaire is available upon request)

Analysis was carried out in three stages. First, the sexes were compared regarding their average scores on all eleven traits using a $t$-test. Second, to determine how well the eleven traits correlated with one another, a correlation matrix was created for the sexes separately.
Third, factorial analysis was performed on the eleven traits to assess whether or not some of the traits would form into clusters.

\section{RESULTS}

Table 1 shows that all eleven androgen-promoted traits are significantly more pronounced in men than in women, with $p=0.000$ in all cases except for eye color (which attained significance only at the 0.05 level). This is entirely predictable, given that the levels of testosterone (and other androgens) are higher for males than for females throughout both the organizational and activational stages of sexual differentiation ([1], pp. 89-93).

Table 2, however, reveals that within each sex, some of the androgen-promoted traits are not positively correlated with one another. Such a rather surprising finding can be interpreted as suggesting that the enhancement of androgen-promoted traits does not occur through a unitary process. Most notably, the variables of eye color and especially adolescent facial acne correlate negatively with many of the other androgen-influenced traits among both sexes.

The results for factor analyzing responses regarding the eleven androgen-promoted traits are presented in Table 3 for each sex separately. Regarding males (Table 3(a)), the first factor to emerge was named masculinity / strength since it was comprised of masculine mannerisms, masculine body build, and all three of the physical strength measures. We named the second factor pigment because it only loaded strongly on hair color and eye color. Body hair development and adolescent facial acne loaded most heavily on the third factor (with some secondarily strong loadings on upper and lower body strength), which was named dark pigmentation. Finally, height and low-deep voice comprised a fourth factor, which we named physical prowess since both height and low-deep voice are likely to have evolved primarily to intimidate rivals (and possibly impress prospective mates).

Turning to females (Table 3(b)), four factors also emerged. The first factor had to do with strength. Masculine mannerisms and body build loaded along with low-deep voice onto a second factor; therefore, we called it female masculinity. The remaining two female factors were identical to those in males, a dark pigmentation factor and a skin-hair factor. It is interesting to note that height loaded heavily on the physical prowess factor in males but failed to load on any factor among females.

\section{CONCLUSIONS}

While there is no doubt that androgens play a pivotal role in differentiating males from females, much remains 
Table 1. Descriptive statistics for androgen-promoted physical traits by comparing males with females.

\begin{tabular}{|c|c|c|c|c|c|c|c|}
\hline Traits & $\mathrm{N}$ & Mean & $\begin{array}{l}\text { Std. } \\
\text { Dev }\end{array}$ & $\begin{array}{c}\text { Effect } \\
\text { Size } \\
\text { (d) }\end{array}$ & $\begin{array}{c}\text { Variance } \\
\text { Explained }\end{array}$ & $\begin{array}{l}\text { Std. Error } \\
\text { Mean }\end{array}$ & $\begin{array}{l}\text { t-Test Results for } \\
\text { Equality of Means }\end{array}$ \\
\hline \multicolumn{8}{|c|}{ Masculine Mannerisms } \\
\hline Female & 7,456 & 21.84 & 21.89 & 2.59 & 0.62 & 0.254 & $132.748 * * *$ \\
\hline Male & 3,757 & 74.88 & 74.88 & & & 0.309 & \\
\hline \multicolumn{8}{|c|}{ Masculine Body Appearance } \\
\hline Female & 7,447 & 12.90 & 19.27 & 3.32 & 0.74 & 0.223 & $165.808 * * *$ \\
\hline Male & 3,767 & 76.82 & 19.29 & & & 0.314 & \\
\hline \multicolumn{8}{|c|}{ Physical Strength } \\
\hline Female & 7,697 & 60.48 & 18.89 & 0.52 & 0.06 & 0.215 & $26.473 * * *$ \\
\hline Male & 3,786 & 70.00 & 17.72 & & & 0.288 & \\
\hline \multicolumn{8}{|l|}{ Height } \\
\hline Female & 6,655 & 65.15 & 2.70 & 2.05 & 0.51 & 0.033 & $95.150 * * *$ \\
\hline Male & 3,282 & 70.88 & 2.88 & & & 0.050 & \\
\hline \multicolumn{8}{|c|}{ Low Deep Voice } \\
\hline Female & 6,540 & 21.22 & 24.84 & 1.38 & 0.32 & 0.307 & $64.699 * * *$ \\
\hline Male & 3,217 & 54.98 & 23.92 & & & 0.422 & \\
\hline \multicolumn{8}{|c|}{ Upper Body Strength } \\
\hline Female & 5,016 & 52.46 & 22.12 & 0.41 & 0.04 & 0.314 & $16.698 * * *$ \\
\hline Male & 2,483 & 61.57 & 22.23 & & & 0.446 & \\
\hline \multicolumn{8}{|c|}{ Lower Body Strength } \\
\hline Female & 5,834 & 57.91 & 21.19 & 0.38 & 0.03 & 0.279 & $16.136^{* * *}$ \\
\hline Male & 2,827 & 65.72 & 21.01 & & & 0.395 & \\
\hline \multicolumn{8}{|c|}{ Body-Hair Development } \\
\hline Female & 5,806 & 46.56 & 21.64 & 0.24 & 0.01 & 0.285 & $10.304 * * *$ \\
\hline Male & 2,828 & 52.06 & 23.96 & & & 0.451 & \\
\hline \multicolumn{8}{|c|}{ Facial Acne } \\
\hline Female & 5,793 & 29.88 & 25.73 & 0.17 & 0.008 & 0.338 & $7.699 * * *$ \\
\hline Male & 2,816 & 34.39 & 25.42 & & & 0.479 & \\
\hline \multicolumn{8}{|c|}{ Hair Color } \\
\hline Female & 6,399 & 2.47 & 1.01 & 0.21 & 0.01 & 0.013 & $9.762 * * *$ \\
\hline Male & 3,128 & 2.68 & 0.99 & & & 0.018 & \\
\hline \multicolumn{8}{|c|}{ Eye Color } \\
\hline Female & 3,881 & 1.84 & 0.90 & 0.05 & 0.003 & 0.014 & $2.249 *$ \\
\hline Male & 2,002 & 1.89 & 0.92 & & & 0.021 & \\
\hline
\end{tabular}

Notes: $\mathrm{p}<0.001=* * *, \mathrm{p}<0.01=* *$, and $\mathrm{p}<0.05=* ; \mathrm{d}=$ Cohen's $\mathrm{d}$

Table 2. Inter-correlation matrix for androgen-promoted traits by sex. The coefficients for males (bolded) appear in the upper right quadrant; those for females (italicized) are in the lower left quadrant (the sample sizes used in calculating each correlation are represented in parentheses).

\begin{tabular}{|c|c|c|c|c|c|c|c|c|c|c|c|}
\hline & $\begin{array}{l}\text { Masculine } \\
\text { Mannerism }\end{array}$ & $\begin{array}{l}\text { Masculine } \\
\text { Body } \\
\text { Build }\end{array}$ & $\begin{array}{l}\text { Physical } \\
\text { Strength }\end{array}$ & $\begin{array}{l}\text { Height } \\
\text { in } \\
\text { inches }\end{array}$ & $\begin{array}{l}\text { Low- } \\
\text { Deep } \\
\text { Voice }\end{array}$ & $\begin{array}{l}\text { Upper } \\
\text { Body } \\
\text { Strength }\end{array}$ & $\begin{array}{l}\text { Lower } \\
\text { Body } \\
\text { Strength }\end{array}$ & $\begin{array}{l}\text { Body } \\
\text { Hair }\end{array}$ & $\begin{array}{l}\text { Facial } \\
\text { Acne }\end{array}$ & $\begin{array}{l}\text { Hair- } \\
\text { color }\end{array}$ & $\begin{array}{l}\text { Eye- } \\
\text { color }\end{array}$ \\
\hline $\begin{array}{l}\text { Masculine } \\
\text { Manner- } \\
\text { isms }\end{array}$ & 1 & $\begin{array}{c}0.737 * * \\
(3,751)\end{array}$ & $\begin{array}{c}0.464 * * \\
(3,756)\end{array}$ & $\begin{array}{l}0.053 * * \\
(3,246)\end{array}$ & $\begin{array}{l}0.190 * * \\
(3,193)\end{array}$ & $\begin{array}{c}0.326 * * \\
(2,458)\end{array}$ & $\begin{array}{c}0.285 * * \\
(2,804)\end{array}$ & $\begin{array}{l}0.129 * * \\
(2,813)\end{array}$ & $\begin{array}{c}-0.121 * * \\
(2,794)\end{array}$ & $\begin{array}{c}0.026 \\
(3,100)\end{array}$ & $\begin{array}{l}0.062 * * \\
(1,980)\end{array}$ \\
\hline $\begin{array}{l}\text { Masculine } \\
\text { Body } \\
\text { Build }\end{array}$ & $\begin{array}{l}0.676 * * \\
(7,423)\end{array}$ & 1 & $\begin{array}{c}0.550 * * \\
(3,766)\end{array}$ & $\begin{array}{l}0.062 * * \\
(3,255)\end{array}$ & $\begin{array}{c}0.206 * * \\
(3,201)\end{array}$ & $\begin{array}{c}0.398 * * \\
(2,468)\end{array}$ & $\begin{array}{c}0.327 * * \\
(2,812)\end{array}$ & $\begin{array}{l}0.149 * * \\
(2,813)\end{array}$ & $\begin{array}{c}-0.098 * * \\
(2,802)\end{array}$ & $\begin{array}{c}0.029 \\
(3,108)\end{array}$ & $\begin{array}{c}0.065 * * \\
(1,987)\end{array}$ \\
\hline $\begin{array}{l}\text { Physical } \\
\text { Strength }\end{array}$ & $\begin{array}{c}0.194 * * \\
(7,447)\end{array}$ & $\begin{array}{c}0.158 * * \\
(7,436)\end{array}$ & 1 & $\begin{array}{c}0.052 * * \\
(3,273)\end{array}$ & $\begin{array}{c}0.215 * * \\
(3,216)\end{array}$ & $\begin{array}{c}0.563 * * \\
(2,478)\end{array}$ & $\begin{array}{c}0.390 * * \\
(2,822)\end{array}$ & $\begin{array}{l}0.102 * * \\
(2,823)\end{array}$ & $\begin{array}{c}-0.123 * * \\
(2,812)\end{array}$ & $\begin{array}{c}0.007 \\
(3,125)\end{array}$ & $\begin{array}{c}0.049 * * \\
(2,001)\end{array}$ \\
\hline $\begin{array}{l}\text { Height in } \\
\text { inches }\end{array}$ & $\begin{array}{c}0.087 * * \\
(6,394)\end{array}$ & $\begin{array}{c}0.089 * * \\
(6,384)\end{array}$ & $\begin{array}{c}0.096 * * \\
(6,629)\end{array}$ & 1 & $\begin{array}{l}0.131 * * \\
(2,738)\end{array}$ & $\begin{array}{c}0.036 \\
(2,381)\end{array}$ & $\begin{array}{c}0.039 \\
(2,375)\end{array}$ & $\begin{array}{c}0.005 \\
(2,376)\end{array}$ & $\begin{array}{r}-0.014 \\
(2,364)\end{array}$ & $\begin{array}{l}-134 * * \\
(2,707)\end{array}$ & $\begin{array}{c}-0.076 * * \\
(1,949)\end{array}$ \\
\hline $\begin{array}{l}\text { Low- } \\
\text { Deep } \\
\text { Voice }\end{array}$ & $\begin{array}{c}0.314 * * \\
(6,332)\end{array}$ & $\begin{array}{l}0.284 * * \\
(6,321)\end{array}$ & $\begin{array}{c}0.144 * * \\
(6,528)\end{array}$ & $\begin{array}{c}0.087 * * \\
(5,496)\end{array}$ & 1 & $\begin{array}{l}0.184 * * \\
(2,470)\end{array}$ & $\begin{array}{l}0.152 * * \\
(2,815)\end{array}$ & $\begin{array}{l}0.149 * * \\
(2,816)\end{array}$ & $\begin{array}{c}0.012 \\
(2,806)\end{array}$ & $\begin{array}{c}0.014 \\
(3,115)\end{array}$ & $\begin{array}{c}0.058 * * \\
(1,994)\end{array}$ \\
\hline $\begin{array}{l}\text { Upper } \\
\text { Body } \\
\text { Strength }\end{array}$ & $\begin{array}{c}0.172 * * \\
(4,814)\end{array}$ & $\begin{array}{c}0.140 * * \\
(4,806)\end{array}$ & $\begin{array}{c}0.476 * * \\
(5,006)\end{array}$ & $\begin{array}{c}0.063 * * \\
(4,844)\end{array}$ & $\begin{array}{c}0.130 * * \\
(4,961)\end{array}$ & 1 & $\begin{array}{c}0.588 * * \\
(2,477)\end{array}$ & $\begin{array}{l}0.288 * * \\
(2,475)\end{array}$ & $\begin{array}{r}-0.030 \\
(2,463)\end{array}$ & $\begin{array}{c}0.007 \\
(2,408)\end{array}$ & $\begin{array}{l}0.060 * \\
(1,704)\end{array}$ \\
\hline $\begin{array}{l}\text { Lower } \\
\text { Body } \\
\text { Strength }\end{array}$ & $\begin{array}{c}0.170 * * \\
(5,632)\end{array}$ & $\begin{array}{l}0.100 * * \\
(5,624)\end{array}$ & $\begin{array}{c}0.401 * * \\
(5,824)\end{array}$ & $\begin{array}{c}0.083 * * \\
(4,837)\end{array}$ & $\begin{array}{c}0.113 * * \\
(5,783)\end{array}$ & $\begin{array}{c}0.648 * * \\
(5,002)\end{array}$ & 1 & $\begin{array}{l}0.282 * * \\
(2,823)\end{array}$ & $\begin{array}{r}-0.008 \\
(2,811)\end{array}$ & $\begin{array}{c}0.014 \\
(2,741)\end{array}$ & $\begin{array}{c}0.033 \\
(1,700)\end{array}$ \\
\hline Body Hair & $\begin{array}{c}0.073 * * \\
(5,607) \\
\end{array}$ & $\begin{array}{c}0.060 * * \\
(5,597)\end{array}$ & $\begin{array}{c}0.049 * * \\
(5,796)\end{array}$ & $\begin{array}{l}-0.019 \\
(4,808) \\
\end{array}$ & $\begin{array}{c}0.086 * * \\
(5,756)\end{array}$ & $\begin{array}{c}0.266 * * \\
(4,969)\end{array}$ & $\begin{array}{c}0.279 * * \\
(5,791)\end{array}$ & 1 & $\begin{array}{c}0.066 * * \\
(2,811) \\
\end{array}$ & $\begin{array}{l}0.058 * * \\
(2,742) \\
\end{array}$ & $\begin{array}{c}0.035 \\
(1,701) \\
\end{array}$ \\
\hline
\end{tabular}




\begin{tabular}{|c|c|c|c|c|c|c|c|c|c|c|c|}
\hline $\begin{array}{l}\text { Facial } \\
\text { Acne }\end{array}$ & $\begin{array}{c}0.080 * * \\
(5,592)\end{array}$ & $\begin{array}{c}0.046 * * \\
(5,585)\end{array}$ & $\begin{array}{c}-0.026^{*} \\
(5,783)\end{array}$ & $\begin{array}{c}0.016 \\
(4,796)\end{array}$ & $\begin{array}{c}0.052 * * \\
(5,743)\end{array}$ & $\begin{array}{c}0.082 * * \\
(4,947)\end{array}$ & $\begin{array}{c}0.089 * * \\
(5,772)\end{array}$ & $\begin{array}{l}0.211 * * \\
(5,745)\end{array}$ & 1 & $\begin{array}{r}-0.015 \\
(2,730)\end{array}$ & $\begin{array}{c}-0.073 * * \\
(1,693)\end{array}$ \\
\hline $\begin{array}{l}\text { Hair- } \\
\text { color }\end{array}$ & $\begin{array}{c}-0.039 * * \\
(6,153)\end{array}$ & $\begin{array}{l}-0.021 \\
(6,141)\end{array}$ & $\begin{array}{c}-0.028^{*} \\
(6,382)\end{array}$ & $\begin{array}{c}-0.075 * * \\
(5,489)\end{array}$ & $\begin{array}{c}0.022 \\
(6,331)\end{array}$ & $\begin{array}{c}-0.035^{*} \\
(4,858)\end{array}$ & $\begin{array}{c}-0.040^{*} \\
* \\
(5,663)\end{array}$ & $\begin{array}{l}0.081 * * \\
(5,636)\end{array}$ & $\begin{array}{c}-0.028 * \\
(5,622)\end{array}$ & 1 & $\begin{array}{c}0.440 * * \\
(1,998)\end{array}$ \\
\hline $\begin{array}{l}\text { Eye- } \\
\text { color }\end{array}$ & $\begin{array}{l}-0.023 \\
(, 3739)\end{array}$ & $\begin{array}{c}0.001 \\
(3,731)\end{array}$ & $\begin{array}{l}-0.008 \\
(3,871)\end{array}$ & $\begin{array}{c}-0.085 * * \\
(3,824)\end{array}$ & $\begin{array}{c}0.017 \\
(3,847)\end{array}$ & $\begin{array}{l}-0.014 \\
(3,298)\end{array}$ & $\begin{array}{l}-0.010 \\
(3,297)\end{array}$ & $\begin{array}{l}0.052 * * \\
(3,277)\end{array}$ & $\begin{array}{l}-0.017 \\
(3,267)\end{array}$ & $\begin{array}{l}0.442 * * \\
(3,880)\end{array}$ & 1 \\
\hline
\end{tabular}

Note: $* \mathrm{p}<0.05 ; * * \mathrm{p}<0.01$

Table 3(a). Factor Loadings for Androgen-Promoted Traits for Males.

\begin{tabular}{lcccc}
\hline Items & Factor 1 & Factor 2 & Factor 3 & Factor 4 \\
\hline Masculine Mannerism & $\mathbf{0 . 8 0 6}$ & -0.001 & -0.125 & 0.056 \\
Masculine Body Build & $\mathbf{0 . 8 4 5}$ & 0.011 & -0.064 & 0.071 \\
Height & 0.002 & -0.158 & -0.145 & $\mathbf{0 . 8 3 5}$ \\
Low Deep Voice & 0.178 & 0.157 & 0.290 & $\mathbf{0 . 6 3 3}$ \\
Overall Physical Strength & $\mathbf{0 . 7 8 0}$ & 0.059 & 0.043 & 0.082 \\
Upper Body Strength & $\mathbf{0 . 6 7 9}$ & 0.046 & 0.445 & 0.026 \\
Lower Body Strength & $\mathbf{0 . 5 9 2}$ & 0.023 & 0.481 & 0.028 \\
Body Hair & 0.172 & 0.081 & $\mathbf{0 . 6 9 2}$ & 0.066 \\
Facial Acne & -0.263 & -0.154 & $\mathbf{0 . 5 6 6}$ & -0.022 \\
Hair Color & 0.004 & $\mathbf{0 . 8 3 2}$ & 0.018 & -0.064 \\
Eye Color & 0.046 & $\mathbf{0 . 8 2 9}$ & -0.042 & 0.036 \\
\hline
\end{tabular}

Table 3(b). Factor Loadings for Androgen-Promoted Traits for Females.

\begin{tabular}{lcccc}
\hline Items & Factor 1 & Factor 2 & Factor 3 & Factor 4 \\
\hline Masculine Mannerism & 0.091 & $\mathbf{0 . 8 5 6}$ & -0.057 & 0.050 \\
Masculine Body Build & 0.025 & $\mathbf{0 . 8 6 0}$ & -0.015 & 0.000 \\
Height & 0.132 & 0.206 & -0.212 & -0.254 \\
Low Deep Voice & 0.119 & $\mathbf{0 . 5 8 9}$ & 0.063 & 0.017 \\
Overall Physical Strength & $\mathbf{0 . 7 4 6}$ & 0.164 & -0.012 & -0.216 \\
Upper Body Strength & $\mathbf{0 . 8 5 8}$ & 0.096 & -0.024 & 0.134 \\
Lower Body Strength & $\mathbf{0 . 8 2 5}$ & 0.047 & -0.013 & 0.195 \\
Body Hair & 0.299 & 0.017 & 0.123 & $\mathbf{0 . 6 7 7}$ \\
Facial Acne & -0.054 & 0.101 & -0.121 & $\mathbf{0 . 7 7 5}$ \\
Hair Color & 0.004 & 0.002 & 0.009 \\
Eye Color & -0.010 & 0.028 & $\mathbf{0 . 8 3 0}$ & 0.003 \\
\hline
\end{tabular}

to be learned about which androgens are involved in particular traits and when they have their greatest influences. The present study sheds light on the process by suggesting that in both sexes, four independent factors emerge when eleven androgen-promoted physiological traits are measured. The structures of these four factors are slightly different for males and for females.

In males, the primary factor loads most heavily on masculinity and strength, whereas in females, the load- ing is strictly on strength. We hypothesize that in both sexes this primary factor is the result of perinatal and postpubertal exposure to testosterone. This hypothesis is consistent with studies showing that testosterone is by far the most consequential sex hormone regarding both masculine mannerisms [46] and muscular strength [15, 41]. To explain why mannerisms in females would not be masculinized by testosterone, we suspect that the levels of this hormone to which most females are exposed 
are insufficient to significantly affect this trait while muscular strength responds to even low amounts of testosterone. Another possibility is that high (female-typical) exposure to estradiol or other female hormones may counteract the effects of testosterone on masculine mannerisms.

The fact that the same factors for the dark pigmentation factor and the skin-hair factor emerged in both sexes suggests that these traits are a) the result of androgens other than testosterone, and b) that the androgen(s) primarily responsible for hair growth and facial acne is different from those influencing hair and eye color.

Regarding the three questions posed in the introduction, one can conclude the following: First, all eleven traits that other studies have shown to be androgenpromoted are, as expected, more pronounced in males than in females. Second, within each sex, most of the eleven traits are positively correlated. The fact that there are exceptions leads one to expect that different androgens are operating in somewhat different ways within each sex. Third, factor analysis supports this expectation by demonstrating that there are four clusters of androgen-promoted traits amongst the eleven traits examined in the present study. We named these four factors and hypothesized that testosterone is responsible for the first (and most prominent) factor for both sexes. In males, this primary factor involved both strength and masculine mannerisms, while in females it only involved strength.

Research is needed to verify these four factors and to look for other androgen-promoted traits within each sex. In future studies, direct measurement would almost certainly provide more reliable data than self-reports. However, the time required for obtaining direct measures with a sufficiently large sample of subjects needed for factor analysis could be prohibitive. It can also be said that the extent to which people can provide accurate information about themselves may surpass expectations. In this regard, we compared the average heights of our subjects to estimates recently given by the Center for Disease Control based on direct measurements [48]. The results were very similar: 70.88 inches or $5^{\prime} 9.1$ " tall in our male sample compared to $5{ }^{\prime} 9.2$ " for the national sample, and 65.15 inches or $5{ }^{\prime} 4.3$ " tall in our female sample compared to $5^{\prime} 3.8$ ' for the national sample.

If the four factor structure of androgen-promoted traits revealed in the present study can be replicated, the next phase in this line of research would be to identify each of their specific causes. In other words, what are the actual androgens involved in producing each factor and what is the developmental timing involved?

\section{REFERENCES}

[1] Ellis, L., Hershberger, S., Field, E., Wersinger, S., Pellis,
S., Geary, D., Palmer, C., Hoyenga, K., Hetsroni, A. and Karadi, K. (2008) Sex differences: Summarizing more than a century of scientific research. Psychology Press, New York.

[2] Alexander, G.M., Welcox, T. and Farmer, M.E. (2009) Hormone-behavior associations in early infancy. Hormones and Behavior, 56, 498-502.

[3] Cooke, B., Hegstrom, C.D., Villeneuve, L.S. and Breedlove, S.M. (1998) Sexual differentiation of the vertebrate brain: Principles and mechanisms. Frontiers in Neuroendocrinology, 19, 323-362.

[4] Lutchmaya, S., Baron-Cohen, S., Raggatt, P., Knickmeyer, R. and Manning, J. (2004) 2nd to 4th digit ratios, fetal testosterone and estradiol. Early Human Development, 77, 23-28.

[5] Zucker, K.J., Beaulieu, N., Bradley, S.J., Grimshaw, G.M. and Wilcox, A. (2001) Handedness in boys with gender identity disorder. Journal of Child Psychology and Psychiatry, 42, 767-776.

[6] Dennis, C. (2004) Brain development: The most important sexual organ. Nature, 427, 390-392.

[7] Goodfellow, P.N. and Lovell-Badge, R. (1993) SRY and sex determination in mammals. Annual Review of Genetics, 27, 71-92.

[8] Jost, A., Price, D. and Edwards, R.G. (1970) Hormonal factors in the sexual differentiation of the mammalian foetus. Transactions of the Royal Society of London, 259, 119-130.

[9] Woodson, J.C. and Gorski, R.A. (2000) Structural sex differences in the mammalian brain: Reconsidering the male / female dichotomy. In: Malsumoto, A. Ed., Sexual Differentiation of the Brain, CRC Press, Boca Raton, 229239.

[10] Vergnaud, G., Page, D.C., Simmler, M.C., Brown, L., Rouyer, F., Noel, B., et al. (1986) A deletion map of the human Y chromosome based on DNA hybridization. American Journal of Human Genetics, 38, 109-124.

[11] Jost, A. (1983) Genetic and hormonal factors in sex differentiation of the brain. Psychoneuroendocrinology, 8, 183193.

[12] Carruth, L.L., Reisert, I. and Arnold, A.P. (2002) Sex chromosome genes directly affect brain sexual differentiation. Nature Neuroscience, 5, 933-934.

[13] Ellis, L. (1996) The role of perinatal factors in determining sexual orientation. In: Savin-Williams, R.C. and Cohen, K.M. Eds., The Lives of Lesbians, Gays, and Bisexuals: Children to Adults, Harcourt Brace, New York, 35-70.

[14] Cohen-Bendahan, C.C., van de Beek, C. and Berenbaum, S.A. (2005) Prenatal sex hormone effects on child and adult sex-typed behavior: Methods and findings. Neuroscience and Biobehavior Review, 29, 353-384.

[15] Fink, B., Thanzami, V., Seydel, H. and Manning, J.T. (2006) Digit ratio and hand-grip strength in German and Mizos men: Cross-cultural evidence for an organizing effect of prenatal testosterone on strength. American Journal of Human Biology, 18, 776-782.

[16] Seale, J.V., Wood, S.A., Atkinson, H.C., Lightman, S.L. and Harbuz, M.S. (2001) Organizational role for testosterone and estrogen on adult hypothalamic-pituitary- adrenal axis activity in the male rat. Endocrinology, 146, 1973-1982. 
[17] Sisk, C.L. and Zehr, J.L. (2005) Pubertal hormones organize the adolescent brain and behavior. Frontiers in Neuroendocrinology, 26, 163-174.

[18] Marshall, W.A. and Tanner, J.M. (1970) Variations in the pattern of pubertal changes in boys. Archives of Disease in Childhood, 45, 13-23.

[19] Lookingbill, D.P., Demers, L.M., Wang, C., Leung, A., Rittmaster, R.S. and Santen, R.J. (1991) Clinical and biochemical parameters of androgen action in normal healthy caucasian versus chinese subjects. Journal of Clinical Endocrinology and Metabolism, 72, 1242-1248.

[20] Giltay, E.J. and Gooren, L.J. (2000) Effects of sex steroid deprivation / administration on hair growth and skin sebum production in transsexual males and females. Journal of Clinical Endocrinology \& Metabolism, 85, 29132921.

[21] Morejohn, G.V. and Genelly, R.E. (1961) Plumage differentiation of normal and sex-anomalous ring-necked pheasants in response to synthetic hormone implants. The Condor, 63, 101-110.

[22] Coplan, R.J., Coleman, B. and Rubin, K.H. (1998) Shyness and little boy blue: Iris pigmentation, gender, and social wariness in preschoolers. Developmental Psychobiology, 32, 37-44.

[23] Farthing, M., Mattei, A.M., Edwards, C.R.W. and Dawson, A.M. (1982) Relationship between plasma testosterone and dihydrotestosterone concentrations and male facial hair growth. British Journal of Dermatology, 107, 559-564.

[24] de Waal, W.J., Torn, M., de Muinck Keizer-Schrama, S.M.P.F., Aarsen, R.S.R. and Drop, S.L.S. (1995) Long term sequelae of sex steroid treatment in the management of constitutionally tall stature. Archives of Disease in Childhood, 73, 311-315.

[25] Thiboutot, D. (2003) Acne: Hormonal concepts and therapy. Clinics in Dermatology, 22, 419-428.

[26] Bubenik, G.A. and Bubenik, A.B. (1985) Seasonal variations in hair pigmentation of white-tailed deer and their relationship to sexual activity and plasma testosterone. Journal of Experimental Zoology, 235, 387-395.

[27] Toro, J., Turner, M. and Gahl, W.A. (1999) Dermatologic manifestations of hermansky-pudlak syndrome in patients with and without a 16-base pair duplication in the hps1 gene. Archives of Dermatology, 135, 774-780.

[28] Cassorla, F.G., Skerda, M.C., Valk, I.M., Hung, W., Cutler, G.B. and Loriaux, D.L. (1984) The effects of sex steriods on ulnar growth during adolescence. Journal of Clinical Endocrinology and Metabolism, 58, 717-720.

[29] Bourguignon, J.P., Vandeweghe, M., VanderschuerenLodeweyckx, M., Malvaux, P., Wolter, R., Du Caju, M., et al. (1986) Pubertal growth and final height in hypopituitary boys: A minor role of bone age at onset of puberty. Journal of Clinical Endocrinology and Metabolism, 63, 376-382.

[30] Zemel, B.S. and Katz, S.H. (1986) The contribution of adrenal and gonadal androgens to the growth in height of adolescent males. American Journal of Physical Anthropology, 71, 459-466.

[31] Martin, M.M., Martin, A.L. and Mossman, K.L. (1986) Testosterone treatment of constitutional delay in growth and development: Effect of dose on predicted versus definitive height. Acta Endocrinology Supplement, 279,

\section{7-152.}

[32] Jassal, S.K., Barrett-Connor, E. and Edelstein, S.L. (1995) Low bioavailable testosterone levels predict future height loss in postmenopausal women. Journal of Bone and Mineral Research, 10, 650-654.

[33] Butler, G., Walker, R.F., Walker, R.V., Teague, P., Riad, F. and Ratcliffe, S. (1989) Salivary testosterone levels and the progress of puberty in the normal boy. Clinical Endocrinology, 30, 487-596.

[34] Harries, M., Hawkins, S., Hacking, J. and Hughes, I.A. (1998) Changes in the male voice at puberty: Vocal fold length and its relationship to the fundamental frequency of the voice. Journal of Laryngology and Otology, 112, 451-454.

[35] Dabbs, J.M. and Mallinger, A. (1999) High testosterone levels predict low voice pitch among men. Personality and Individual Differences, 27, 801-804.

[36] Nieschlag, E. and Zitzmann, M. (2001) Testosterone levels in healthy men and the relation to behavioural and physical characteristics: Facts and constructs. European Journal of Endocrinology, 144, 183-197.

[37] Bruckert, L., Lienard, J.-S., Lacroix, A., Kreutzer, M. and Leboucher, G. (2006) Women use voice parameters to assess men's characteristics. Proceedings of the Royal Society B, 273, 83-89.

[38] Hamilton, J.B. (1948) The role of testicular secretions as indicated by the effects of castration in man and by studies of pathological conditions and the short lifespan associated with maleness. Recent Progress of Hormonal Research, 3, 257-322.

[39] Wang, C., Eyre, D.R., Clark, R., Kleinberg, D., Newman, C., Iranmanesh, A., et al. (1996) Sublingual testosterone replacement improves muscle mass and strength, decreases bone resorption, and increases bone formation markers in hypogonadal men: A clinical research center study. Journal of Clinical Endocrinology and Metabolism, 81, 3654-3662.

[40] Joubert, Y., Tobin, C. and Lebart, C. (1994) Testosterone-induced masculinization of the rat levator ani muscle during puberty. Developmental Biology, 162, 104-110.

[41] Perry, H.M., Miller, D.K., Patrick, P. and Morley, J.E. (2000) Testosterone and leptin in older African-American men: Relationship to age, strength, function, and season. Metabolism, 49, 1085-1091.

[42] Iannuzzi-Sucich, M., Prestwood, K.M. and Kenny, A.M. (2002) Prevalence of sarcopenia and predictors of skeletal muscle mass in healthy, older men and women. Journals of Gerontology Series A: Biological Sciences and Medical Sciences, 57, M772-M777.

[43] Bosinski, H.A.G., Schroder, I., Peter, M., Arndt, R., Wille, R. and Sippell, W.G. (1997) Anthropometrical measurements and androgen levels in males, females, and hormonally untreated female-to-male transsexuals. Archives of Sexual Behavior, 26, 143-157.

[44] Wang, C., Swerdloff, R.S. and Iranmanesh, A. (2000) Transdermal testosterone gel improves sexual function, mood, muscle strength, and body composition parameters in hypogonadal men. Journal of Clinical Endocrinology and Metabolism, 85, 2839-2853.

[45] Whalen, R.E. and Edwards, D.A. (1967) Hormonal determinants of the development of masculine and feminine behavior in male and female rats. Anatomical Record, 
157, 173-180.

[46] Goy, R.W., Bercovitch, F.B. and McBrair, M.C. (1988) Behavioral masculinization is independent of genital masculinization in prenatally androgenized female rhesus macaques. Hormones and Behavior, 22, 552-571.

[47] Ellis, L. and Cole-Harding, S. (2001) The effects of prenatal stress, and of prenatal alcohol and nicotine expo- sure, on human sexual orientation. Physiology and Behavior, 74, 213-226.

[48] Ogden, C.L., Fryar, C.D., Carroll, M.D. and Flegal, K.M. (2004) Mean body weight, Height, and body mass index, United States 1960-2002. Advance Data from Vital and Health Statistics, 347, 1-18. 